\title{
Qualitative Increase in Family Economic Income is a Stimulus for Women Doing Business Case Studies in Urban Market Tasek Raja, Pasir Mas, Kelantan
}

\author{
Azlina Musa
}

\begin{abstract}
This paper will discuss qualitative increase in family economic income is a stimulus for women doing business case studies in urban market Tasek Raja, Pasir Mas, Kelantan. This paper will examine the contribution of women in business to help improve the family economy. Also identifies the type of business and how managing their time with their families. Examining how the perceptions of the community around women are doing business. What is the key to the success of women in business. Examine Kelantan women's phenomenon diligently working compared to men. This paper is obtained through field methods such as observation, interviews and questionnaires with one hundred women. Through the re-documentation of this assessment, can further supplement the source of reference to other researchers in the future.
\end{abstract}

Keywords: Women, Business, Family Economy, Income.

\section{INTRODUCTION}

Urban market Tasek Raja is market located in Pasir Mas, Kelantan. Urban market Tasek Raja has started its business in 2016. Urban market Tasek Raja between urban Pasir Mas, Salor, Rantau Panjang and as well boundary Sungai Golok. Urban market Tasek Raja is a large strategic market that has become the focus of the public. Urban market Tasek Raja is a big market that has become the main focus of the people living in Pasir Mas to get various daily necessities.

The existence of urban market Tasek Raja has provided employment opportunities to the surrounding population. As well as providing the essentials and services needed by every resident on daily basis. Position urban market Tasek Raja close to the Thailand border has facilitated Thailand items brought in by raw items suppliers. Every Thailand items is brought in by through boundary Sungai Golok and items are sold at cheaper prices to Malaysian traders. Hence Malaysian traders will buy items from Thailand suppliers and sells items to buyers who come in urban market tasek Raja. This causes urban market tasek raja always be the focus of the people and the people outside the district Kelantan to get stuff such as groceries, fruits, vegetables and something else in urban market tasek raja. Urban market tasek raja providing women's space in the market. Women woke up early to cook at home and out as early as morning then spend time all day business in the market and women

Revised Manuscript Received on April 19, 2019.

Azlina Musa, Pusat Pendidikan Asas dan Liberal, Universiti Malaysia Terengganu, 21030 Kuala Nerus, Terengganu, Malaysia. go back at home in the afternoon. Allocate women time more all day business for increase income for the growing family needs. Even business, women still role as a mother, wife for cooking, washing clotches, managing children and husband as well as homework.

\section{URBAN MARKET TASEK RAJA}

Urban market Tasek Raja is basic economic activity women business is contributors development economic sector. Urban market tasek raja is a new market upgraded to replace old market is located the train station in Pasir mas, Kelantan. Construction again upgraded urban market tasek raja is better to compared old market. Urban market tasek raja which has built a covered building is more comfortable to compared old market a bit worn out and not so comfortable to traders. If the old market business should wear canopy, wooden table to place a sale items to traders especially when the rainy season or strong windy season. Strong windy season and storm can cause canopy flying in the wind. Construction urban market tasek raja is women needs to rent shop let to do business the roofed and comfortable with rental rates. All convenience provided urban market tasek raja for comfortable visitors. Between convenience provided as bus station, taxi service, toilet, mosque and car parking.

Besides be found food outlets which provided cooked in the morning and hot food to visitors stop by urban market tasek raja. Urban market tasek raja became a great crowd such as food, vegetables, clothes and something else in urban market tasek raja. Urban tasek raja will started business at 5.00 a.m and closed business at 7.00 p.m.

Overall business urban market tasek raja is a women monopolized. Engagement women as a dealer has been interesting attention visitors to stop shopping items in urban market tasek raja. Besides price of an items is cheap in urban market tasek raja. This is because the items sold is artificial stuff obtained from Thailand suppliers. This cause items sold cheaper than supermarket. Besides visitors go urban market tasek raja because business activities monopolized by women.

\section{BUSINESS WOMEN}

Women play a role in developing a family. Women are

Published By:

Blue Eyes Intelligence Engineering

$\&$ Sciences Publication 
not just to shoulder the responsibility as wife which manages husband, children and house. Women role managing cooking, washing clothes and cleaning the houses. While task women on the outside is related with community development generally which included women in economy sector, politic, social and community.

Women play a role in development economy sector is played by Saiditina Khadijah that is the first wife Rasulullah s.a.w and is a women entrepreneurs that succed business. Suhili Nain (1999), Nabi Muhammad s.a.w has taken place marriage with Khadijah Binti Khuwalid which is women entrepreneur among the Arabs. Take a lesson Khadijah Binti Khuwalid is a woman's spirit Kelantan hardworking business. Women working at the same level man. High spirited of women which is in woman cause woman more noble and more diligent to compared a man which is deemed as lazy and spend a lot time at the coffee shop with friends.

\section{METHODOLOGY}

Methodology qualitative includes observations, interviews and questionnaire. Respondent sampling consists of 100 women doing business activities at urban market tasek raja. The largest majority urban market tasek raja is managed Malay women Muslim. Overall women Muslim is veiled.

Every one women speech is a nature gentle, kindly, generous with a smile. There are old women dealers the generous give charity the items sold to buyers. Besides bargaining happens between women dealers and buyers. Women buyers want to get cheap stuff and women buyers as comfortable buy items sold by women traders.

Frequency of generosity applicable to 85 respondent women who do business vegetables, fruits. Examples women buyers buy vegetables. But women free gift add items for buyers as chili. Then 15 respondent women traders not generous free gift especially stuff such as mat, pot, bed sheets. Wisdom and intelligence women in business activities interest buyers often come in stores.

Fluent in dialect Kelantan during business activities between women and buyers. Be found 95 respondent women is a origin of birth Kelantan. While 5 respondent women are active business origin of birth Thailand. Thailand women marriage Kelantan man doing business.

Between types of activity business the largest women in urban market tasek raja is 70 respondent women doing business such as groceries. While 20 respondent doing business such as vegetables. Then 10 respondent women such as fruits.

Layout conditions is somewhat organized in urban market tasek raja at 8.00 a.m. loyout conditions items in urban market tasek raja between 5.00 a.m until 7.55 a.m not organized on the outside of the building urban market tasek raja. The presence of Thailand suppliers which sells items a low price. This effects source of local business. At 8.00 a.m Thailand suppliers leaving the building outside in urban market tasek raja. This phenomenon often happens every day by Thailand suppliers take a lot of profit. This affects the income of local traders.

\section{RESULTS AND FINDINGS}

Generally business activity run by traders woman is a contributor which helps reduce burden economy family. Women doing business help added income economy family. When the husband is working and woman is working helps added income economy family. If the wife does not work cause income low income economy family.

The majority of the traders who manage small business activities in the market of the king's beaches are monopolized by Muslim women who conduct business. There are various types of businesses run by women in the market. Among the businesses are marketing of vegetables, fruits, artificial cosmetics, fruits, chickens, fish, groceries, kitchen utensils, traditional cakes and more. Lot of retail space conducted by the dealer is obtain permission from the District Council of Pasir Mas, Kelantan. Most of the lot of retail space is based on space rental for business. Accordingly, the rental for each lottery space is between RM100 and RM150. Each lot of rental lot price is different depending on the size of the lot space for the business owner.

While the women's operating hours in the town market of tasek raja are women out of the house to work in the market town of raja tasek to do business starting at 5.00 am to 7.00 $\mathrm{pm}$. The majority of women working in the town market of the king of Tasek is a trader who carries out their lifelong business to cater for the needs of the family economy. This is because, a majority of female respondents of 100 female businessmen stated that they are lifelong traders who will carry on their lifelong business to support their family life needs.

The focus is on women traders who carry out business activities to assist the family economy. If the sexes are found to be the majority of traders in the market of the king's beaches is 95 per cent of the business activities in the market of the king's beaches are dominated by business women. While 5 percent are business activities conducted by men businessmen. This situation shows that business is very comfortably monopolized by women than men. This suggests that different customers of sex either men or women prefer to buy items sold by women traders. Additionally, customers like to buy items sold by women traders because of the softness and courtesy properties of women traders as customers prefer to buy goods sold with women traders. In addition, buying and selling deals are also comfortable between customers and women traders. In addition, men are getting smaller in business in the market because men prefer to do a fairly coarse and rugged job like being a homemaker, going down and so on.

Next is 83 female business respondents aged 60 years and above. While 10 female respondents are 40 to 50 years old. Next 5 female respondents are aged 30 to 20 who carry out business activities in the market town of the king of Tasek. This suggests that women doing business in the market are women of ages who carry out small-scale business activities in the market of the royal shrine. 


\section{VI.}

TRADITIONAL WOMEN FACTORS IN THE MARKET

Women are trading in the market because women have a hereditary background of business, women business interests. Besides women doing business because of single mother status, high cost of living, living poverty and a lazy man works.

\section{A. Women Have A Hereditary Background of Business}

Women has background the ancestral ancestry of the business. Be found 85 respondent women has background the ancestral ancestry of the business. Blood lineage grandmother or grandfather doing business has been touched women doing business. The inheritance of the business to children for business interests. Then 10 respondent women doing business because interested business to get financially. While 5 respondent women business because have no education, does not go to school and there are only primary schools. Low education affects women doing business. This affects women doing business because of low education affects women to trade in the market.

\section{B. Women Of Single Mother Status}

There are 11 respondents who trade women because of single mother status. Single maternal status due to husband's death, divorce has prompted women to trade in the market for financial support for daily meals and schooling expenses. Next 6 female respondents trade because the husband has lost the ability to work due to certain diseases such as stroke, diabetes, paralysis, bodily injury due to severe road accidents. Husbands who lost their ability to work have made women out of business because their husbands have lost their ability to work for life. Women should be out of business to support the lives of their children. While 2 respondents women are single status who have encouraged them to trade in the market.

\section{High Cost Of Living}

The willingness of women to trade because of the high cost of living today. Overall, 100 female respondents feel very burdened with the very high cost of living today. This is because the price of expensive necessities has encouraged women to do business.

\section{Women Has Wanted Satisfaction}

There are women who want to buy luxury for themselves. Women trade because they do not want to expect money from their husbands. This is why women are willing to go out to work early in the morning to work to fulfill their selfesteem and the luxury of women who can not afford men.

There are 90 respondents of women's businessmen who say they like to work in business because they earn daily income through business. In addition to the money used for the remaining savings used to achieve living satisfaction. Earn money earned through a business is used to purchase items desired by women. The item is incapable of being given through the husband's money. After women are selfemployed they do not have to depend on the financial resources of men. Women can be self-reliant through income earned business. Despite being small business, however, women are able to achieve satisfaction through small businesses conducted.
Thus, the income of women in business can be used to buy home appliances such as furniture, crockery, clothes, gold for the satisfaction of luxury through self-employed. This is due to a man who can not fulfill all the desires and satisfaction desired by women. This makes women willing to do business solely to achieve their own satisfaction and luxury. The level of entrepreneurial satisfaction among women increased after an increase in revenue through sales of businesses that received a response from buyers.

\section{E. Poverty Of Live}

In general, women trade is caused by poverty. Hence the shortage of income sources and the large number of children has prompted women to trade. There were 93 respondents of business women who had ten children and above. Meanwhile, 5 female respondents with 6 children and above. Next 2 female respondents had 1 to 5 children. Hence the number of large children and living poverty has encouraged women to trade.

\section{F. Women Would Love Welcome To The People}

The majority of female respondents are happy to do business in the market because they are getting rid of the burden at home and want to get more friends where they work. This is because the whole business woman is happy with the work of doing business because around them are mostly women who work together in the market. In addition, women trade because they want to get more friends to share stories and chat. Thus, business activity is found that women have many friends and can easily get any information from friends at work. It is about other business opportunities that women can get through business and want to increase their business income through their business contacts.

\section{G. Settlement Of Family Financial Economic Solutions}

Problems in financial constraints in the family also encouraged 100 female respondents to wake up early in the morning and leave work at $5.00 \mathrm{am}$. At that time, customers consisting of wholesalers, traders who are food traders will often go out to find the ingredients needed at $5.00 \mathrm{am}$. Additionally, at 5.00 am the price of materials brought in by Thai suppliers through the Thai border to be supplied to Malaysian traders in the market of the king's shrimp city is cheap. In addition, as early as 5.00 am there are many visitors to get their daily necessities. This is because at the moment the price of the goods is sold very cheaply by Thai suppliers. This situation encourages visitors to buy their essential goods in the morning to get cheap prices from Thai suppliers.

\section{H. Man Of Lazy Works}

There are 10 respondents of business women are due to her husband who has no permanent job. Husband is just working in a village waiting for seasonal and uncertain work. Between husband's job is working as a grassman in the village. Husband's work as a lawn mower is waiting for work if the grass machine service is needed in the village. If the lawnmower service does not at the moment cause men 
do not work.

In addition, Pasir Mas's men are as lively as possible to work. The men of Pasir Mas are fond of friends and love entertainment activities like gambling, fighting against work for families. Men Pasir Mas is said to be dependent on sources of income of wife working to accommodate family needs. In addition, men's rest time is more time spent at home and being friends or entertaining with their friends in the village. In addition, there are men who are still doing work such as homemakers in the village, tapping rubber, downhill and being a stroller to carry goods. Employment as a home builder is a seasoned job. If there is no house to build, men will sleep more, relax and spend their time at home. So women will go out everyday to run small businesses in the market. Hence the work of women is only for the sake of family life. There are even men who play the role of nurturing and caring for the many children at home while the women are out of business.

\section{Traditional Women For Want To Help Husband} Business

There are 5 female businessmen in the market of the town of tasek raja is due to help the husband's business. This is because, husbands and wives go out early in the morning to carry out daily routine work as a business in the market. Women go out to trade because they want to help a husband's business who do not have a business assistant. Particularly in the business of groceries, fruits, eateries involves husband and wife in business. Women go out to work to help ease the burden of a husband, especially when many shoppers stop at their store, allowing time to rotate their husbands and wives to keep the store especially for prayers, for a meal break. In addition, when a woman goes out of business it also helps her husband to pack and lift items and organize the items in the store to be neat and tidy. Apart from that, the wife goes out of business because her husband can not afford the salaries of the shop assistant because business income is only able to sustain life alone. Business income is dependent on buyers who stop at their store. If on the day of sale blank shoppers stop at their store cause they go home with empty income to the house.

In addition, the peculiarity of the market in the town of Pasir Mas in Pasir Mas compared to other existing markets is that there is a rented toll payment in the market town of raja tasek which has charged a certain charge to enter the market which is according to the time of visitors stopping in and out to the market town of tasek raja . Overall 100 women respondents disagreed with the existence of paid cross-border tolls in the market. Before the existence of the crossed toll it was found that the visitors were very crowded into the market town of the king of Tasek. However, paid toll bills have resulted in decreased buyers. Sometimes a buyer only enters a short interval in the market to buy only the necessary items for not being willing to put a vehicle in the market for too long to be unable to pay a daily crossborder toll. There are also buyers who take the initiative to buy goods in other markets that do not charge crossed toll charges. Hence, the entire female trader in the town market of the king's beaches is dissatisfied with the crossed toll charges as some of them have affected their source of income which is indeed working as a business to support their children's needs all day long.

In addition, business income is seasonal and uncertain as well as expecting customers who come to buy in their stores. Thus the income of the business is uncertain and seasonal in everyday business. However, seasonal income in the business includes festive seasons, school holidays and general holidays working women earn lucrative income through the business. During the holiday season there are many buyers of migrant children from outside Kelantan who return to hometowns, tourists or overseas Kelantan take a chance to go to the market of the town of tasek raja to buy their necessities. There are 90 women respondents who earn RM1500 a month and above when the holiday season. Usually it involves groceries business. Thus, retail businesses provide lucrative income returns to women traders. 10 female respondents earn RM1000 per month for food premises business and 5 female respondents earn RM500.00 per month for fruit, vegetable business. Every income earned resulted in a very excited woman with the work they were doing. Thus women are able to leave children at home to go to work in the market. Women trade because of increasing their family's economic income.

\section{CONCLUSION}

The involvement of women in business in the market of the town of tasek raja has helped donate the economic resources of the family. Increasingly every day women start trading at the market. business is in line with women who are naturally possessing tenderness and have the power to serve every buyer who is dragging in their store

\section{REFERENCES}

1. Ashadi Zain, Rahsia Bisnes Isteri Nabi: Khadijah. Kuala Lumpur: PTS Profesional Publishing Sdn. Bhd., 2008.

2. Suhili Nain, Kunci Kejayaan daripada Hidup Nabi. Kuala Lumpur: Dewan Bahasa dan Pustaka, 1999.

3. Suwandi, Muhammad Hakimi Mohd Shafiai \& Wan Nasyrudin Wan Abdullah, Konsep Perniagaan Islam kajian al-Quran dan al-Sunnah, Jurnal Sultan Sulaiman Shah, 3(2): 65-79.

\section{AUTHORS PROFILE}

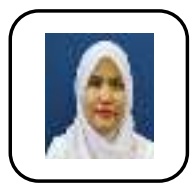

Azlina Musa, Study Pusat Pendidikan Asas dan Liberal, Universiti Malaysia Terengganu 